\title{
Impact of a 1755-like tsunami in Huelva, Spain
}

\author{
V. V. Lima ${ }^{1}$, J. M. Miranda ${ }^{1}$, M. A. Baptista ${ }^{1,2}$, J. Catalão ${ }^{1}$, M. Gonzalez ${ }^{3}$, L. Otero ${ }^{3}$, M. Olabarrieta ${ }^{3}$, \\ J. A. Álvarez-Gómez ${ }^{4}$, and E. Carreño ${ }^{4}$ \\ ${ }^{1}$ University of Lisbon, IDL, Campo Grande, Ed. C8, 1749-016 Lisboa, Portugal \\ ${ }^{2}$ Instituto Superior de Engenharia de Lisboa, IPL, Lisboa, Portugal \\ ${ }^{3}$ Environmental Hydraulic Institute, IH Cantabria, Universidad de Cantabria, E.T.S.I. Caminos, Canales y Puertos, Avd. Los \\ Castros s/n. 39005 Santander, Spain \\ ${ }^{4}$ Centro Nacional de Información Geográfica, C/ General Ibáñez Ibero, no 3, 28003, Madrid, Spain
}

Received: 9 June 2009 - Revised: 10 November 2009 - Accepted: 18 November 2009 - Published: 26 January 2010

\begin{abstract}
Coastal areas are highly exposed to natural hazards associated with the sea. In all cases where there is historical evidence for devastating tsunamis, as is the case of the southern coasts of the Iberian Peninsula, there is a need for quantitative hazard tsunami assessment to support spatial planning. Also, local authorities must be able to act towards the population protection in a preemptive way, to inform "what to do" and "where to go" and in an alarm, to make people aware of the incoming danger. With this in mind, we investigated the inundation extent, run-up and water depths, of a 1755-like event on the region of Huelva, located on the Spanish southwestern coast, one of the regions that was affected in the past by several high energy events, as proved by historical documents and sedimentological data. Modelling was made with a slightly modified version of the COMCOT (Cornell Multi-grid Coupled Tsunami Model) code. Sensitivity tests were performed for a single source in order to understand the relevance and influence of the source parameters in the inundation extent and the fundamental impact parameters. We show that a 1755 -like event will have a dramatic impact in a large area close to Huelva inundating an area between 82 and $92 \mathrm{~km}^{2}$ and reaching maximum run-up around $5 \mathrm{~m}$. In this sense our results show that small variations on the characteristics of the tsunami source are not too significant for the impact assessment. We show that the maximum flow depth and the maximum run-up increase with the average slip on the source, while the strike of the fault is not a critical factor as Huelva is significantly far away from the potential sources identified up to now. We also show that the maximum flow depth within the inundated area is very dependent on the tidal level, while maximum run-up is less affected, as a consequence of the complex morphology of the area.
\end{abstract}

Correspondence to: V. V. Lima

(vcvalima@gmail.com)

\section{Introduction}

Europe experienced tsunami hazards since historic times, originated from different triggering mechanisms. The Storegga submarine slide ca. 8000 years ago (Bondevik et al., 2003) on the Norwegian Sea is the oldest well established event; it originated a wave that reached the Norwegian coast and north UK, according to the sedimentary evidence (Bondevik et al., 2005). In the eastern Mediterranean area a few large events have been studied, like the early Byzantine tectonic and tsunami events ca. 365 AD (Pirazzoli, 1996), the Sicily $1693 \mathrm{AD}$ and the Calabria $1783 \mathrm{AD}$ earthquakes and tsunamis (Tinti and Maramai, 1996; Gutscher et al., 2006) and the 1908 Messina earthquake and tsunami (Tinti and Maramai, 1996).

Within the Gulf of Cadiz area, the largest well studied event is the great Lisbon 1755 earthquake and tsunami (Baptista et al., 1998a, b; Solares, 2001; Solares and Arroyo, 2004). It stroke the Portuguese, the Spanish and the Northern African coasts, severely damaging near shore localities, as described by a large amount of historical documents that testify the impact of the tsunami waves. The inundation generated an important sedimentological signature (e.g. Dawson et al., 1995). Looking into the geological record along the southern part of Spain, at Gulf of Cadiz, in the Doñana National Park, Ruiz et al. (2005) identified tsunamigenic deposits ca. $5300 \mathrm{BP}, 4182-4152 \mathrm{BP}$ and 3862-3763 BP. They proposed the existence of two main sequences of events of great magnitude, with returning periods of 2000 years, between which there would be a difference of about 300 to 400 years (Ruiz et al., 2005). Luque et al. (2001) investigated tsunami deposits in the Gulf of Cadiz: they identified three tsunami-generated deposits and also deduced an average interval of about 2000 years between two consecutive events. 


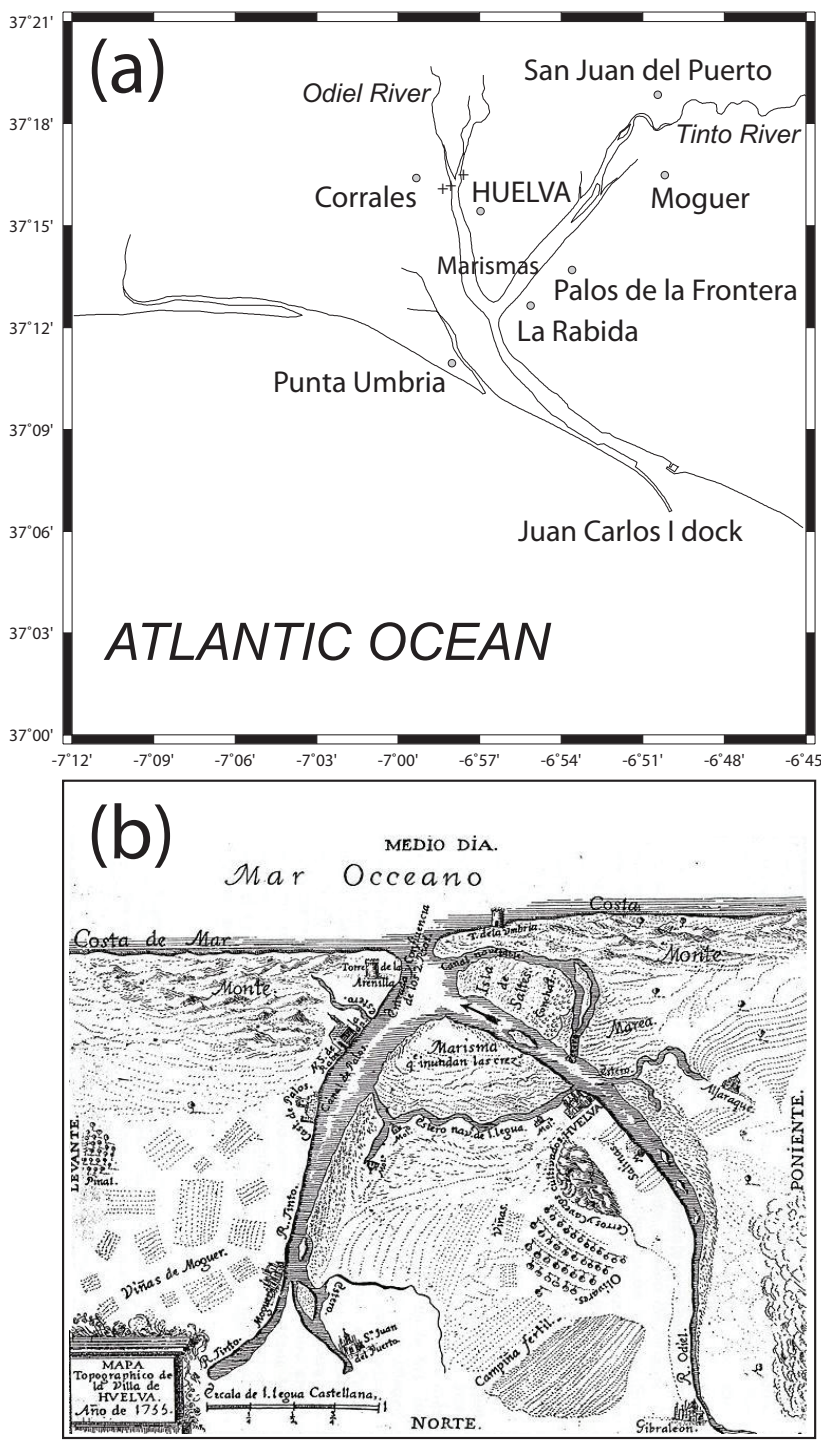

Fig. 1. Geographic sketch of the study. In (a) the three crosses located between Corrales and Huelva represent the location of the cores studied by Morales et al. (2008). (b) is a reproduction of a coeval map of the area obtained from the "Mapa Topográfico de Huelva y los Lugares colombinos, del siglo XVIII. Spain. La Rábida. Historia documental crítica. 1925”.

Even if the probable recurrence period for 1755-like events is quite large, there is enough evidence to support the existence of similar events in the historical period (Baptista and Miranda, 2009). In this sense there is a need to estimate the impact of a similar event nowadays in the southern Iberian coasts. Similar studies have already been performed for the UK (Kerridge, 2005; Horsburgh et al., 2008) including tsunami sources in the Gulf of Cadiz.

In this work we focus on the area of Huelva, southern Spain. Flooding is computed using a non-linear shallow water approach (Liu et al., 1994a, b) and a new compilation of bathymetric and topographic data. We investigate the expected flooding area and the inundation parameters for several candidate sources obtained from recent research developed in the Gulf of Cadiz (Zitellini et al., 2009). The impact of the tsunami inundation is analyzed using the computed maximum flow depths.

To assess the accuracy of the inundation maps produced we test the sensitivity of some basic inundation indicators, such as maximum run-up and maximum flow depth, towards reasonable changes in source geometry and slip. Results obtained are checked against historical descriptions and geological data. Also we analysed the run-up evolution in Huelva for each of the studied faults. This work is a contribution to the TRANSFER EU project.

\section{Impact of the 1755 tsunami on Huelva coast}

Huelva was the Spanish city which suffered most from the 1755 earthquake and tsunami (IGN, 2005). Most of the information available comes from a survey made by the Castile Council in 1755. In the Nuevo y Curioso Romance (1775) we can read that the earthquake occurred, "at ten in the morning [...]". From the original documents the local time of perception of the event in Cadiz was 09:52 UT, according to Solares and Arroyo (2004), giving an inferred origin time at the focus of 10:16 UT. In Huelva the earthquake made the population move away to las Marismas (salt marshes) where they thought it would be safe (Romero, 1992, taken from El Informe de la Academia; cf. Fig. 1a and b for locations).

Water agitation was noticed later and the occurrence is reported as follows: "[...] amid such confusion, the river left running, the sea blew up and the waters gathered quickly". The destruction was very large: "[...] as the sea blew up, and the river, more than 1000 people died, destroying temples and houses, and helping the few neighbors that were left, it was announced that in the Convent de la Victoria part of its Temple fell, the Great Altar". The arrival time of the tsunami is evaluated by Romero (1992) as 10:45 UT, quoting El Informe de la Academia: "[... ] Forty five minutes after the end of the quake the sea moved furiously, and pulled the waters onto the coast in such a way that it was believed that the submersion of the town was inevitable".

The maximum inundation distance (MID) was rather large due in particular to the large shallow areas of Huelva region: "From a distance of two leagues from the Bar, and nevertheless water mountains arrived through las Marismas. The river went out and its waves entered the first streets, causing the flood of the marshlands and strangely uplifted the boats". Tsunami waves inundated the streets and through las Marismas propagated and traveled roughly a distance of about 2 leagues $(\sim 11 \mathrm{~km})$.

According to Romero (1992) the sea water entered the mouth of the Odiel mingling with the water from the own river, which originated greater flooding and inundation of the 
streets near the river, although the town location is considerably far from the coast. The water flooded enough to get to la Placeta, in the heart of nowadays Huelva town.

There were three remarkable waves that produced extensive inundation: "[...] The first movement of the sea was a withdraw, exposing more than one quarter of a league $(\sim 1.4 \mathrm{~km})$ of the beach, which was followed by a rush with furious speed against the coast, removing and destroying whatever resisted $[\ldots]$. The tide restored its regular and uniform order within $24 \mathrm{~h}$, and during this period the waters maintained extraordinary movement. The violence of the waves lost gradually its impulse [...]. The place called La Mojarra between La Villa and Ayamonte, which was the most suitable for sardine fishing, remained flooded and only slightly exposed. The Bar of the river was closed and its mouth moved to a distance of two rifle shots".

The reports indicate that the beaches were the most affected areas by the tsunami and that notorious geomorphologic variations were pointed out: "[...] In the Island of Saltes, or Hercules, which is located at the entrance of the Bar in the confluence of rivers Odiel and Tinto (cf. Fig. 1b) two openings were formed so effective and deep that having the Sea flooded that area it discharged through them [...]" (Romero, 1992).

Geological investigation was conducted in several sites in the south of Portugal and Spain to search for evidence of high-energy events, and in particular for the sedimentary signature of the 1755 tsunami. In Portugal, Boca do Rio and Martinhal have been the object of detailed sedimentary studies (Dawson et al., 1995; Hindson et al., 1996). In Spain, deposits have been investigated in the Doñana National Park, close to Huelva (Ruiz et al., 2005) and Valdelagrana spit barrier, in Cadiz (Luque et al., 2001). In the Huelva lowlands, Morales et al. (2008) proposed a link between several sedimentary deposits and tsunami events. Among others, they identified a high-energy layer, which is an exposed shell layer situated in the margins of the erosional banks of the tidal channels of the Odiel Estuary (Fig. 1a). According to Morales et al. (2008), this shell layer has "a linguoidshaped sand body, $400 \mathrm{~m}$ long, $300 \mathrm{~m}$ wide and $1.6 \mathrm{~m}$ thick. The deposit is mainly constituted by clean sand, with a variable content of whole shells and shell fragments, quartzite pebbles, big lumachella fragments, and muddy clasts". A $14 \mathrm{C}$ method was applied to the cores and the authors interpreted this shell layer "as the sedimentary results of the dissipation of the tsunami wave after the 1755 AD Lisbon earthquake" (Morales et al., 2008). They also considered independent age estimates derived from recent sedimentation rates and the presence of abundant lumachella as enough evidence for this conclusion.

\section{Numerical simulations}

\subsection{Bathymetric and DTM models}

The Digital Terrain Model (bathymetry/topography) was generated from a compilation of multisource height/depth data from multibeam surveys, digitalised bathymetric charts of 1:175000 and 1:25000 scales (Folio 93 and 73 of Admiralty Charts and publications) and digital cartographic data of 1:1000 scale. Small and large scale bathymetric charts were merged on a unique database and all data transformed to WGS84/UTM coordinates (fuse 29). On shore, digital height data from 1:1000 topographic charts were supplied by Instituto Geografico Nacional (IGN) of Spain, already on the WGS84/UTM reference system.

The fusion of high resolution depth and height data requires a common definition for the vertical reference surface. Bathymetric charts and topographic charts use different vertical references: the first uses a local reference related with the principal harbour of the chart and the later the mean sea surface for a certain epoch. In this project the zero height (vertical datum) was defined as the mean sea level for 1879-1872, corresponding to the Spanish vertical datum of Alicante, and all depths were converted to this reference.

The zero height contour line obtained from the 1:1000 topographic data were then used as a boundary for landsea transition. Depth and height data were merged subjected to the zero line constraint and carefully edit on the onshore-offshore envelope. The final depth/height dataset was 30756 data points. A TIN (Triangular Irregular Network) with all these data points, including the zero height line as a constraint and break-lines representing surface discontinuities close to the shoreline (harbour, pier, quay), was constructed. A second editing was done and a final grid with $10 \mathrm{~m}$ resolution was computed over the TIN network. Generalizing the $10 \mathrm{~m}$ resolution grid to a $50 \mathrm{~m}$ resolution grid has a smoothing effect that erases most of harbour man-made structures. In order to preserve these main structures an enhancement/exaggeration scheme was applied to the $10 \mathrm{~m}$ resolution grid before the generalization to a $50 \mathrm{~m}$ grid. In the DTM there is no inclusion of buildings. The precision in the vertical coordinate on land is $44 \mathrm{~cm}$ estimated as the standard deviation of the residuals between the grid (50 $\mathrm{m}$ resolution) and the cartographic data. This varies significantly according to the existing charts mainly in the sea.

\subsection{Tsunami sources}

The western Eurasia-Nubia plate boundary extends between the Azores and the western Mediterranean. Along the Azores the interplate domain is rather complex as consequence of the small spreading velocity, though it generates spreading along the Terceira axis. In the area defined between $24^{\circ} \mathrm{W}$ and $19^{\circ} \mathrm{W}$ it is supposed to follow a prominent morphological feature, the Gloria Fault in an almost pure transcorrent 
Table 1. Source parameters for the studied cases.

\begin{tabular}{lrrrrrrrr}
\hline Faults & $\begin{array}{r}L \\
(\mathrm{~km})\end{array}$ & $\begin{array}{r}W \\
(\mathrm{~km})\end{array}$ & $\begin{array}{r}D \\
(\mathrm{~km})\end{array}$ & $\begin{array}{r}\text { slip } \\
(\mathrm{m})\end{array}$ & $\begin{array}{r}\text { Strike } \\
\left({ }^{\circ}\right)\end{array}$ & $\begin{array}{r}\text { Dip } \\
\left({ }^{\circ}\right)\end{array}$ & $\begin{array}{r}\text { Rake } \\
\left({ }^{\circ}\right)\end{array}$ & $M_{w}$ \\
\hline GBF & 137 & 60 & 25 & 8.3 & 233.0 & 25 & 90 & 8.1 \\
HSF & 106 & 70 & 25 & 10.7 & 222.1 & 25 & 90 & 8.2 \\
Ext. MPF & 86 & 70 & 25 & 8.0 & 200.0 & 25 & 90 & 8.0 \\
PBF & 100 & 55 & 25 & 7.2 & 266.3 & 25 & 90 & 8.0 \\
CWF & 133 & 200 & 12 & 11.1 & 346.3 & 6 & 90 & 8.6 \\
\hline
\end{tabular}

way. To the east of $19^{\circ} \mathrm{W}$ the interplate domain is morphologically complex, characterized by a series of huge ridges and seamounts, as the Gorringe Bank, the Coral Patch and Ampère seamounts. These features delimitate morphologically depressions such as the Horseshoe and Tagus abyssal plains and integrate the complex Southwestern Iberian Transpressive zone.

All known catastrophic tsunamis in SW Iberia were triggered by earthquakes even if landslides are also a common phenomenon, but mainly concerns smaller, or local, events (Baptista and Miranda, 2009). In this sense, we must consider as probable sources the main active faults in the SW Iberian margin, whose dimensions are compatible with the generation of at least an $M \sim 8$ earthquake.

The search for active faults in the Gulf of Cadiz able to generate large earthquakes and tsunamis, has been actively conducted by a number of teams, mainly based on the intensive use of multi-channel seismic and high resolution swath bathymetry surveys (see Zittelini et al., 2008 and references herein), and cannot be considered a closed question, in particular because none of the well established faults is able to generate alone the large 1755 event, and correctly reproduce all known historical data. To simulate the effects of a large tsunami in the Gulf of Cadiz one must, nevertheless, rely on the best available geological knowledge and consider the potential effect of all relevant candidate sources.

Selected candidate sources were fixed using simplified geometries, as depicted in Table 1 and sketched in Fig. 3. The selected sources correspond all to thrusts, positively identified on multi-channel seismic profiles (cf. Fig. 3), with quaternary activity, and longer than $50 \mathrm{~km}$. The strike and length of each source was obtained from multichannel seismic research (Zitellini et al., 2009). The width and average slip were fixed using scaling relationships (see Manighetti et al., 2007 and references herein) and geological constrains for the thickness of the seismogenic zone. Most of the sources considered in this study are pure thrusts, where we considered a rake of $90^{\circ}$, a dip of $25^{\circ}$ and an epicentral depth of $25 \mathrm{~km}$. This epicentral depth is taken as the geometric center of the rectangular fault plane.

For the purpose of this study we considered five candidate sources (cf. Table 1): the first one corresponds to the northern flank of the Gorringe Bank, a large stratigraphic discon- tinuity and an area of widespread seismicity; the second one identified by Zitellini et al. (2009) is the Horseshoe Fault, a reverse fault oriented perpendicular to the present day kinematic displacement of Nubia with respect to Iberia; the third one is the Marques de Pombal fault, an active compressive tectonic structure located $100 \mathrm{~km}$ offshore SW Cape San Vicente, with a pronounced drag fold on the fault hanging-wall and the height of the escarpment is taller in the north where it reaches $1.2 \mathrm{~km}$ and where we considered in its maximum possible length; the fourth one is the Portimão Bank Fault, which follows the southern flank of the Guadalquivir and Portimão Banks; the fifth one, the Cadiz Wedge Fault, corresponds to the interpretation made by Gutscher et al. (2006) that the Alboran lithospheric slab could act as a potential seismogenic and tsunamigenic generator. For modeling purposes all these sources are geometrically simplified as described in Table 1.

\subsection{Numerical model}

We used the code COMCOT, Cornell Multi-grid Coupled Tsunami Model (Liu et al., 1994a, 1995, 1998; Wang and Liu, 2006a), to model tsunami propagation and run-up. It is a finite-difference Non Linear Shallow Water (NLSW) tsunami code, able to simulate the generation, propagation, and inundation, run-up and rundown, of a tsunami on coastal regions, using a nested grid scheme. It uses an explicit leap-frog finite difference scheme to solve the shallow water equations in spherical or Cartesian coordinates. This model has already been used to investigate several historical tsunami events, such as the 1960 Chilean tsunami (Liu et al., 1994b), the 1992 Flores Islands (Indonesia) tsunami (Liu et al., 1994b, 1995), the 2003 Algeria Tsunami (Wang and Liu, 2005) and more recently the 2004 Indian Ocean tsunami (Wang and Liu, 2006b; 2007). It also adopts a moving boundary scheme to track the moving shoreline. The code solves numerically the following set of equations:

$$
\begin{aligned}
& \frac{\partial \eta}{\partial t}+\frac{\partial P}{\partial x}+\frac{\partial Q}{\partial y}=0, \\
& \frac{\partial P}{\partial t}+\frac{\partial}{\partial x}\left(\frac{P^{2}}{H}\right)+\frac{\partial}{\partial y}\left(\frac{P Q}{H}\right)+g H \frac{\partial \eta}{\partial x}+\tau_{x}=0, \\
& \frac{\partial Q}{\partial t}+\frac{\partial}{\partial x}\left(\frac{P Q}{H}\right)+\frac{\partial}{\partial y}\left(\frac{Q^{2}}{H}\right)+g H \frac{\partial \eta}{\partial y}+\tau_{y}=0 .
\end{aligned}
$$

Here $\eta$ is the free surface elevation, $h$ is the still water depth, $H$ is the total water depth, $\boldsymbol{u}=\left(u_{x}, u_{y}\right)$ is the velocity vector, $P$ and $Q$ are the volume flux components in $x$ and $y$ directions respectively, $\tau_{x}$ and $\tau_{y}$ are the bottom frictional terms. The expressions for $P$ and $Q$ are respectively:

$$
\begin{aligned}
& P=H u_{x}, \\
& Q=H u_{y} .
\end{aligned}
$$




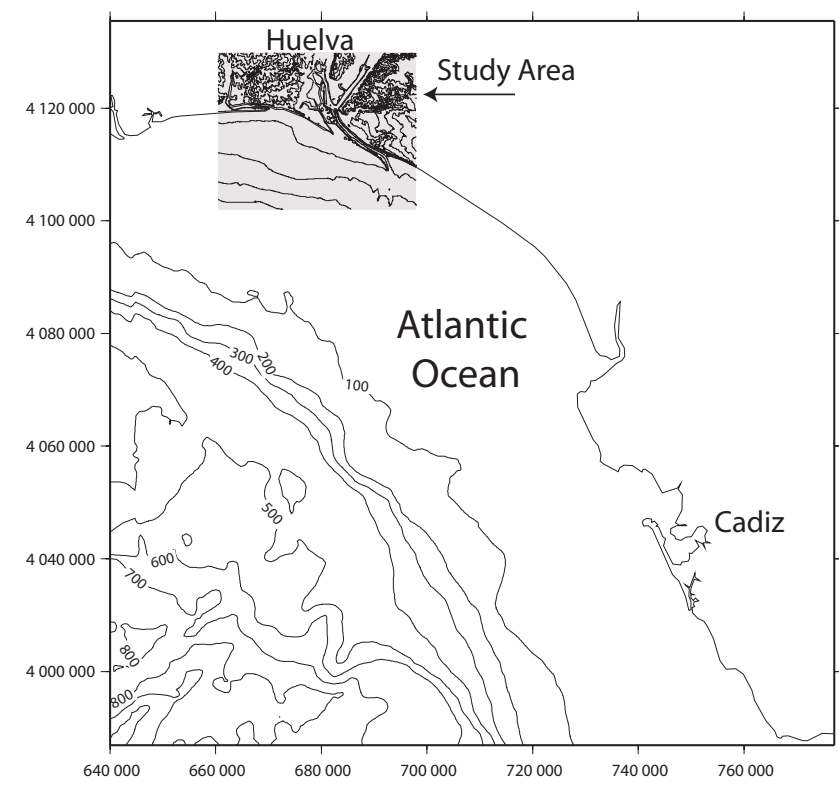

Fig. 2. The area studied in this work is located around Huelva. The terrain model has a resolution of $50 \mathrm{~m}$. For the study of the tsunami propagation a broader area was considered, covering the tectonic sources presented in Fig. 3, where the geographical resolution was $800 \mathrm{~m}$. An intermediate $200 \mathrm{~m}$ grid was also used. The relationship between the three nested grids is displayed in Figs. 2 and 3. Coordinates shown are UTM, zone 29, and represented in $\mathrm{m}$. In the inset, topography is plotted every $10 \mathrm{~m}$.

The total water depth is

$H=h+\eta$.

The numerical scheme used is the explicit leap-frog scheme where $\eta$ is evaluated at the centre of a grid cell, $(i, j)$ grid point, on time step $(n+1 / 2)$-th. $P$ and $Q$ are evaluated on the $n$-th time step at the surrounding points of $(i, j)$ which are the centre of the four sides of the grid cell. The code has also the option to use only the linear set of equation disregarding the non-linear terms in Eqs. (1)-(3).

A small set of modifications was made to the original code: they concern the use of binary input and output files and the computation of maximum flow depth and degree of hazard (Richardson, 2006) during inundation. This version was benchmarked using Catalina Island Meeting case tests (Third International Workshop on Long-wave Run-up Models, 2004). It was observed that the model reproduces acceptably the benchmarks results for tests \#1, \#2 and \#3, the ones relevant for this study, in terms of maximum runup/run-down for the case of Benchmark test \#1, using a step size of $50 \mathrm{~m}$, as used here.

Nested grids have resolutions of $800 \mathrm{~m}, 200 \mathrm{~m}$, and $50 \mathrm{~m}$ (Fig. 2), respectively, in order to assure a good description of bathymetric and topographic effects near shore. The finer

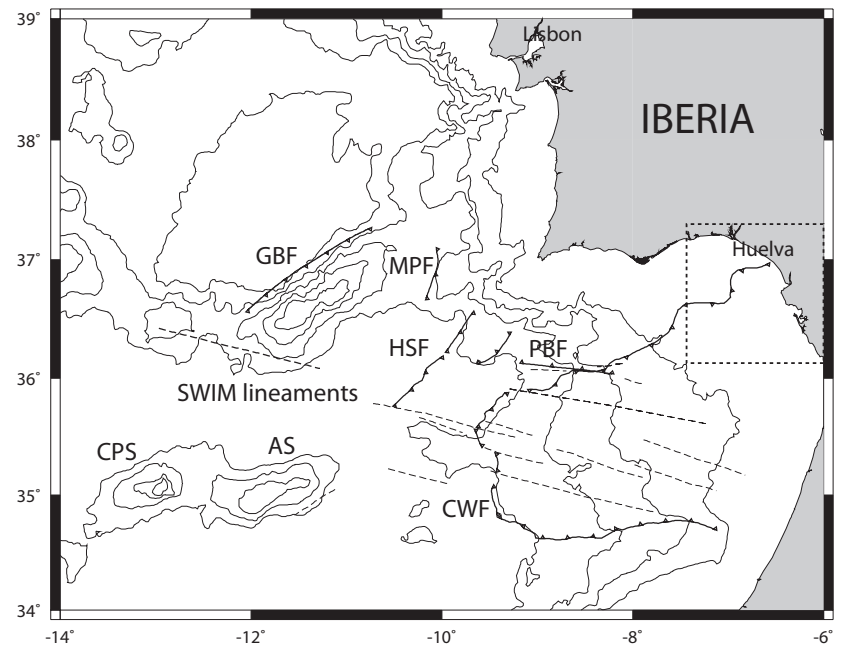

Fig. 3. Tectonic sketch adapted from Zitellini et al. (2009). CWF, Cadiz Wedge Fault; GBF, Gorringe Bank Fault; HSF, Horseshoe Fault; MPF, Ext. Marquês de Pombal Fault; PBF, Portimão Bank Fault; AS, Ampere Seamount; CPS, Coral Patch Seamount. Active thrusts have only been identified north of the SWIM morphological lineaments, interpreted as strike-slip faults by Zitellini et al. (2009). Depth contours plotted every $1000 \mathrm{~m}$. Geographic coordinates.

grid is focused at Huelva close area. All grids are in Cartesian coordinates (UTM 29), which does not correspond to any limitation, seen the size of the study area. The coupling between a sub-grid and their parent grid follows the requirements of Wang and Liu (2006a) and Liu et al. (1998). In the outer grid an open radiation boundary condition is used.

The static vertical displacement of the ocean floor is modelled using Mansinha and Smylie (1971) homogenous elastic half space approach, as implemented in Mirone suite (Luis, 2007). Slip in the source is considered nonhomogeneous, following the smooth closure condition of Geist and Dmowska (1999). No bottom friction was considered.

\section{Results from the numerical model}

Figure 4 shows the results of the maximum flow depth obtained during the simulations with COMCOT for the five candidate sources considered here. The results are presented and confined to the study region of Huelva and its surroundings, as depicted in Fig. 1a. Inundation areas were estimated interactively by directly measurement of the inland areas affected by the inundation. Water depths below $10 \mathrm{~cm}$ were neglected.

In the case of the Gorringe Bank Fault (GBF in Fig. 4) the inundation is small. The salt marshes close to Cadiz are inundated, particularly the Sales Island, where flow depth can locally reach $3 \mathrm{~m}$. Marsh areas at the right margin of Odiel River, west of Cadiz are inundated with a flow depth reaching $1 \mathrm{~m}$. The city itself is not affected. The flooded area reaches $65-75 \mathrm{~km}^{2}$. 

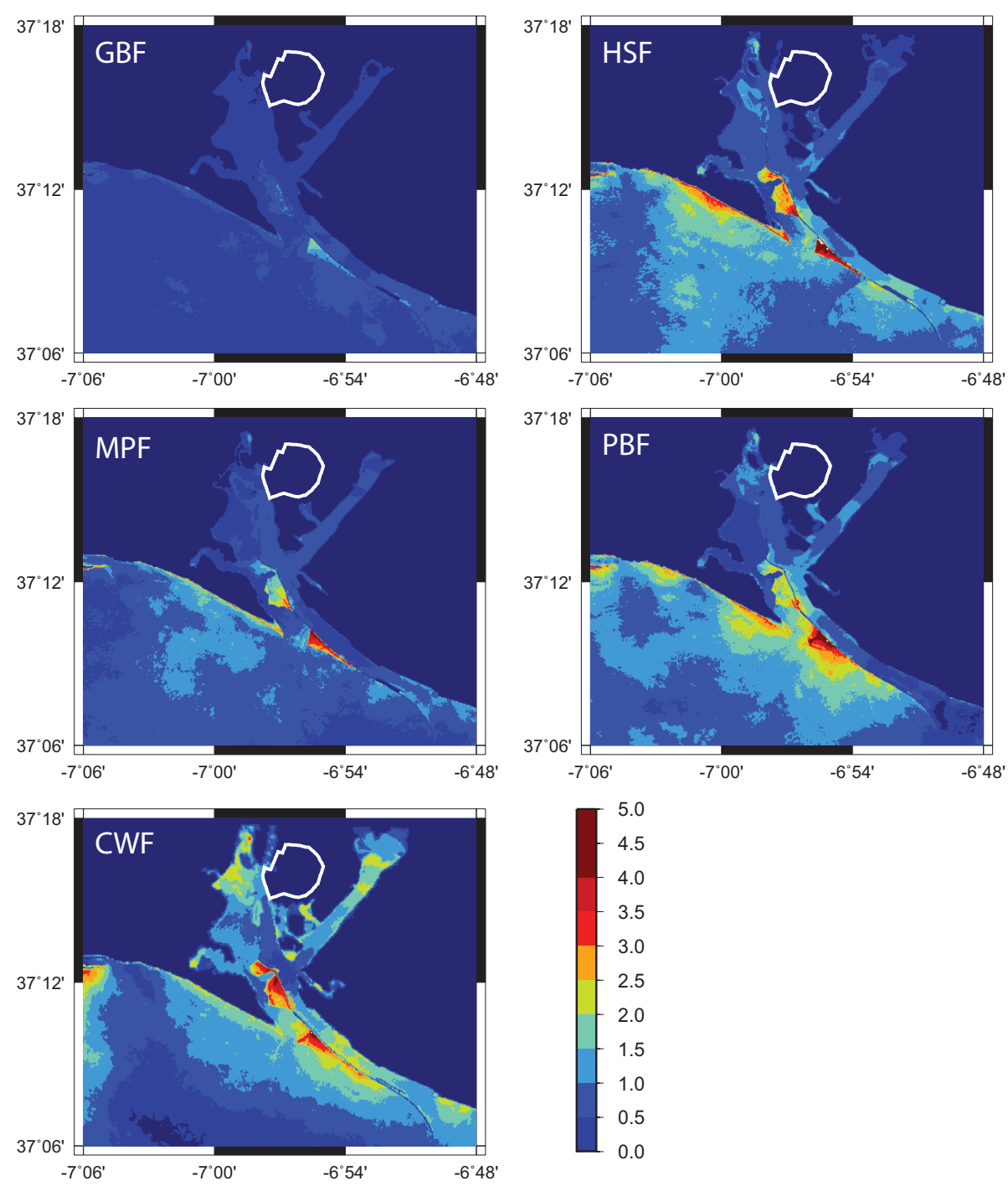

Fig. 4. Maximum flow depth (in $\mathrm{m}$ ) obtained during the simulation in the area of Huelva for the different candidate sources. GBF: Gorringe Bank Fault; HSF: Horseshoe Fault; MPF: Extended Marquês de Pombal Fault; PBF: Portimão Bank Fault, and CWF: Cadiz Wedge Fault. Geographic coordinates. The limit of the main Cadiz urban area is depicted in all cases for an easier comparison.

In the case of the Horseshoe Fault (HSF in Fig. 4) one can observe that the extent and amplitude of the flooding is larger than the simulation made with the Gorringe Bank Fault (GBF in Fig. 4). The area of las Marismas is inundated and a large effect is found along the Odiel River, west of Cadiz city. Large flow depths can be found close to Punta Umbria and along the Sales Island (see Fig. 1 for locations). The flooded area reaches $68-78 \mathrm{~km}^{2}$.

In the case of the extended Marquês de Pombal Fault (MPF in Fig. 4) we have an intermediate situation: the effects are larger than in the case of Gorringe Bank Fault, with higher water depths in las Marismas, but smaller than those observed for Horseshoe Fault. Flooded area reaches $55-65 \mathrm{~km}^{2}$.
In the case of the Portimão Bank Fault (PBF in Fig. 4) the maximum flow depth is more important along the Odiel River, and the run-up reaches $4.4 \mathrm{~m}$. Effects along the Odiel River are similar to those generated by HSF source. We estimate the inundated area between $65-75 \mathrm{~km}^{2}$.

We can observe that the Cadiz Wedge Fault (CWF) floods the whole coastal area, with water depths between 2 and $3 \mathrm{~m}$, maximum $4 \mathrm{~m}$. In las Marismas water depths vary between 2 and $5 \mathrm{~m}$ (cf. Fig.4) as this is a flat and low marshland area (Morales et al., 2008). Flooding reaches areas near Moguer and Palos de la Frontera with probable flooding of Corrales and San Juan de Puerto. CWF generates tsunami waves that travelled far inland mainly through Tinto River channel. La Rábida and the turistic area of Punta Umbria are flooded until a maximum flow depth of $3 \mathrm{~m}$. An estimation for the calculation of the flooded area gives $82-92 \mathrm{~km}^{2}$. 


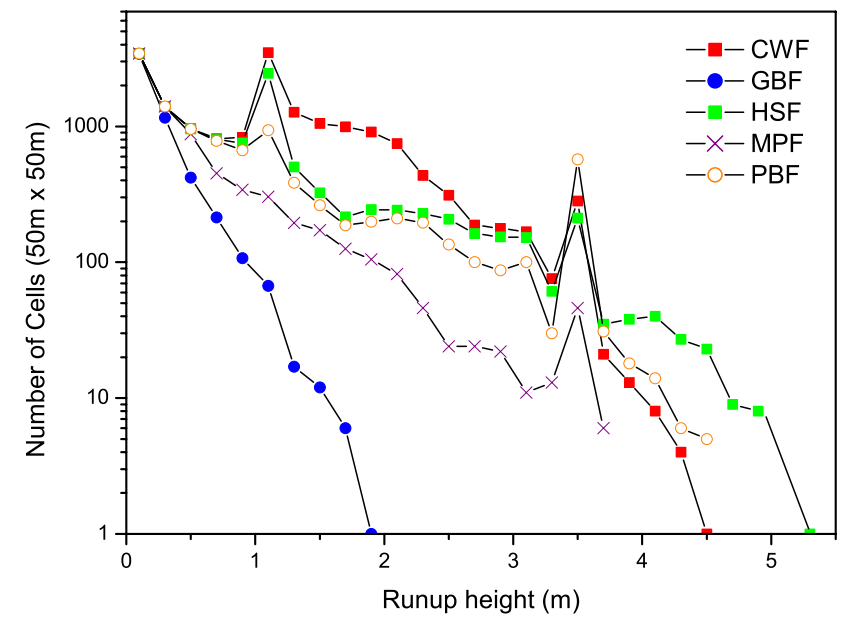

Fig. 5. Distribution of run-up heights within the inundation area, for altitudes greater than $0 \mathrm{~m}$ and flow depths larger than $0.1 \mathrm{~m}$. GBF: Gorringe Bank Fault; HSF: Horseshoe Fault; MPF: Extended Marquês de Pombal Fault; PBF: Portimão Bank Fault; and CWF: Cadiz Wedge Fault.

From the presented descriptions we can conclude that marsh areas are always affected by inundation independently of the source considered (see Fig. 4). In this sense, a particular care must be taken in the preparation plans, to avoid what is documented in El Informe de la Academia, as presented by Romero (1992), when people ran to las Marismas for protection enhancing its vulnerability towards a significant tsunami wave.

Another particularity that can be noticed in the inundation plots concerns the inland extent of the flooding, observing large inundation distances, as this is a very shallow and flat area. Traveling through las Marismas and rivers Odiel and Tinto the water waves reach sites that are considerably far from coastal areas. This is consistent with 1755 descriptions when the river waves flooded the streets of Huelva, traveling a distance of approximately $11 \mathrm{~km}$.

In Huelva area various sedimentary deposits were identified as having tsunamigenic origin (Morales et al., 2008), mainly in shell layers located in the margin of the Odiel Estuary's tidal channels (cf. Fig. 1a). For the three sedimentary deposits locations we see that these sites are flooded in all cases but with different impact levels. A short resume about the main features pointed out before is presented in Table 2.

From the historical reports of the 1755 event, we know that La Placeta, in the centre of Huelva, was flooded; considering this and the results from numerical modeling, we can conclude that even with the "conservative" magnitudes considered in this study the flooding of the area close to Cadiz will occur, in spite of the present harbor defenses and the large infrastructures than also act as protection against the inundation.
Table 2. Maximum flow depths, Run-up and inundation areas for Huelva (cf. Fig. 2b).

\begin{tabular}{|c|c|c|c|}
\hline Faults & $\begin{array}{l}\text { Maximum } \\
\text { Flow Depth } \\
\text { (m) }\end{array}$ & $\begin{array}{c}\text { Run-up } \\
\text { (m) }\end{array}$ & $\begin{array}{c}\text { Flooded } \\
\text { Area } \\
\left(\mathrm{km}^{2}\right)\end{array}$ \\
\hline Gorringe Bank Fault & 2.3 & 1.8 & $55-65$ \\
\hline Horseshoe Fault & 6.3 & 5.2 & $68-78$ \\
\hline Extended Marquês de & & & \\
\hline Pombal Fault & 5.4 & 3.8 & $55-65$ \\
\hline Portimão Bank Fault & 5.8 & 4.4 & $65-75$ \\
\hline Cadiz Wedge Fault & 5.7 & 4.5 & $82-92$ \\
\hline
\end{tabular}

In Fig. 5 we present the distribution of the altitudes of the inundated area for the five candidate sources, considering all areas where the altitude is greater than 0 and the flow depth greater than $0.1 \mathrm{~m}$. The maximum run-up, defined as the highest ground elevation where there is inundation, is well defined in all cases, even when there is a single cell where the maximum is reached (sources GBF and CWF in Fig. 5). Gorringe Bank Fault generates the smallest maximum run-up (close to $2 \mathrm{~m}$ ) and the smallest inundation area (given by the area under the curve displayed in Fig. 5). Marques de Pombal fault has an intermediate effect (maximum run-up close to $3.7 \mathrm{~m}$ ). The other candidate sources generate maximum runup between $4.5 \mathrm{~m}$ and $5.0 \mathrm{~m}$, even if the Cadiz Wedge Fault clearly displays a much larger inundation area, as was already clear from the analysis of Fig. 4.

\section{Sensitivity analysis}

The parameters fixed for the candidate sources were determined from a combination of seismo-stratigraphic identification of active faults, scaling relationships based on average data and general considerations on the kinematics of the Nubian-Eurasian plate boundary. Given all the unknowns on the real parameters of a future event, we must study what is the sensitivity of the results presented here towards reasonable variation of the source parameters.

The sensitivity study is focused on a single structure, namely the Horseshoe Fault (HSF) which was described above. The "free" parameters of the source are the slip, the dip and the strike, and the impact parameters are the maximum flow depth and the maximum run-up. The results are presented in Fig. 6. To plot the run-up in Fig. 6 the maximum highest flooded ground elevation was found for the Horseshoe Fault, for specific studied values of slip $(10.0,10.7$, 12.0, and $15.0 \mathrm{~m})$, Fig. $6 \mathrm{a}$; dip $\left(25^{\circ}, 30^{\circ}, 35^{\circ}, 40^{\circ}, 45^{\circ}, 60^{\circ}\right)$, Fig. 6b; strike $\left(205^{\circ}, 210^{\circ}, 215^{\circ}, 220^{\circ}, 225^{\circ}\right)$, Fig. 6 c, contained in a given interval. Each parameter was varied one at a time and the two other parameters remained constant as listed in Table 1. 

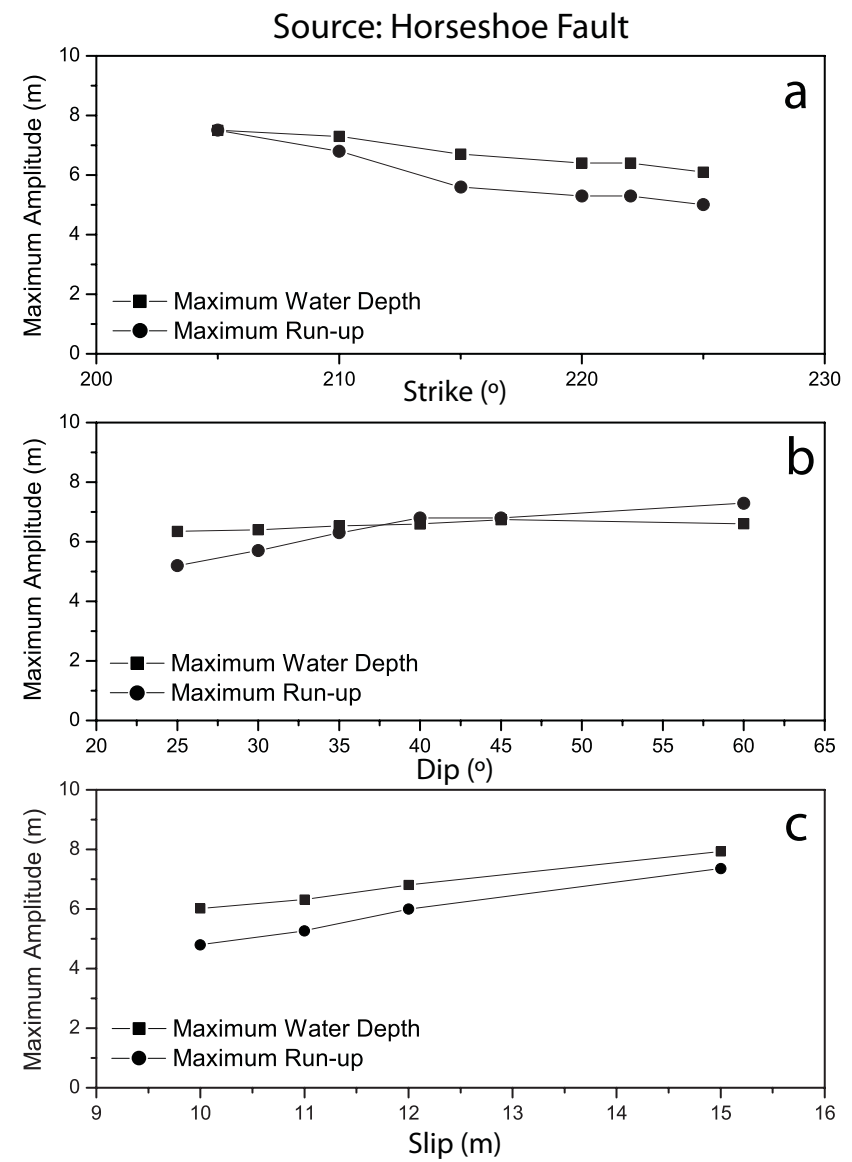

Fig. 6. Sensitivity of tsunami impact parameters in the area of Huelva for the Horseshoe Fault as a function of source parameters Maximum Flow Depth and Maximum Run-up. (a) variation with strike; (b) variation with dip; (c) variation with slip.

Figure 6a shows that both maximum flow depth and maximum run-up increase with decreasing strike, though the maximum flow depth increases slower. Figure $6 \mathrm{~b}$ shows that the maximum flow depth increases with the dip between $25^{\circ}-$ $45^{\circ}$ in a very discrete way and then stabilizes for values of the dip between $45^{\circ}-60^{\circ}$. Maximum run-up increases until $40^{\circ}$, stabilizes between $40^{\circ}$ and $45^{\circ}$ and increases again after. Figure $6 \mathrm{c}$ shows that maximum flow depth increases with slip in a steady way; the same occurs with the maximum run-up for a range of slip values between $10 \mathrm{~m}$ and $15 \mathrm{~m}$, corresponding to moment magnitudes between $M_{w}=8.2$ and $M_{w}=8.3$.

The flooded area for each study case was analysed and roughly determined graphically. Results are compiled in Table 2 .

Finally, we tested the sensitivity of inundation parameters in what concerns tidal levels. Two years of hourly tide values between 1998 and 2000 were used to compute the relative frequency for five different tidal level classes, where the middle class corresponds to mean sea level. Results are presented in Fig. 7.

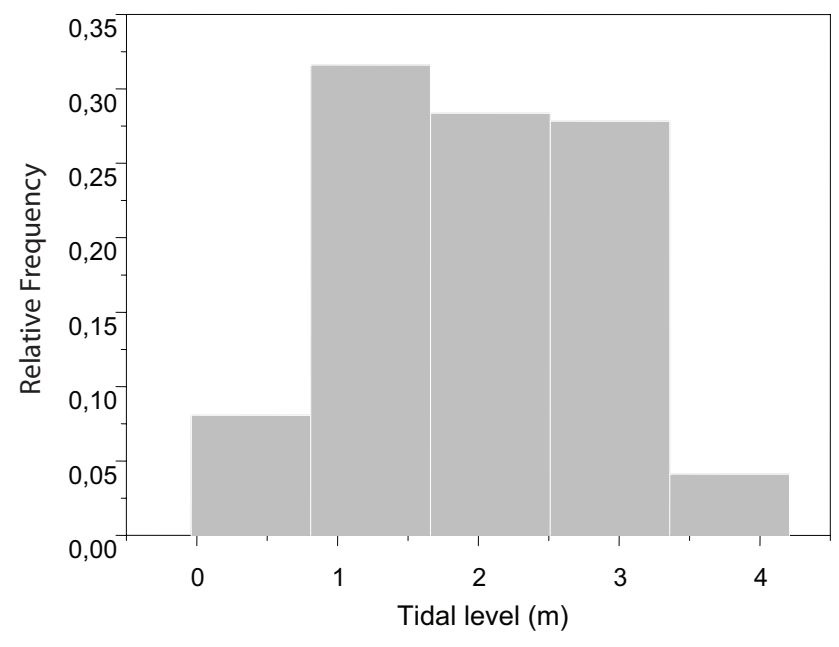

Fig. 7. Tide heights relative frequency, as measured in Huelva tide gauge. Tide heights are referred to the hydrographic vertical datum and we consider five different height classes for the computation of inundation and run-up. Class central values are: $0.385,1.235$, $2.085,2.935$, and $3.785 \mathrm{~m}$ above the hydrographic zero.

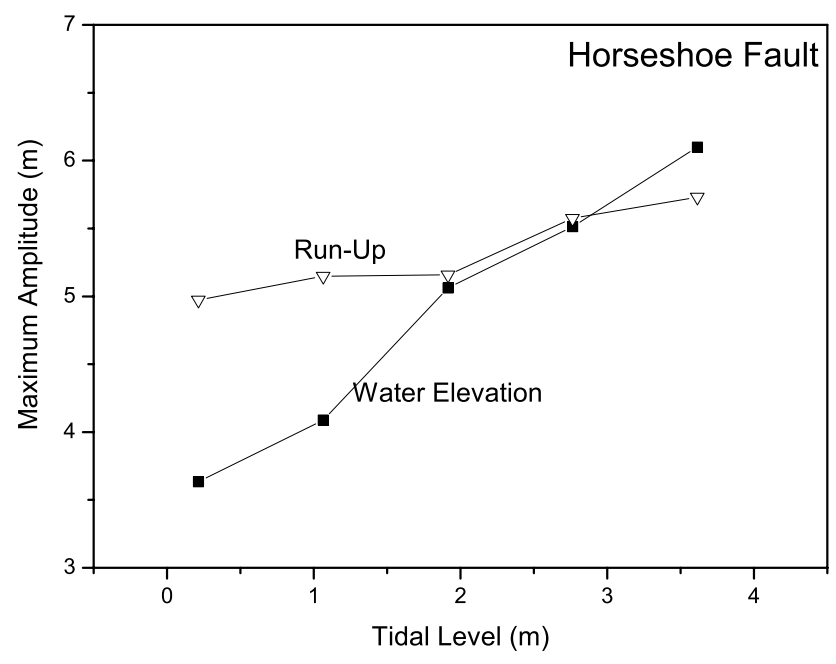

Fig. 8. Sensitivity of tsunami impact parameters (maximum flow depth and maximum run-up) in the area of Huelva for the Horseshoe Fault as a function of tidal levels. Each value corresponds to each class as depicted in Fig. 7. Note that maximum water height changes almost as much as tide level, while maximum run-up increases much slower.

For each class we computed the maximum flow depth and maximum runup. In each case the tide is considered constant all over the studied area. The analysis of Fig. 8 shows that the maximum run-up does not vary significantly with tide level, less than $10 \%$; on the contrary the maximum flow depth varies ca. $40 \%$ with tide. 


\section{Discussion and conclusions}

The range of water depths obtained in the simulations presented before, are clearly sufficient to flood houses and cause considerable destruction in the areas which are closer to the coast. Several populated sites, like Huelva, Punta Umbria, Corrales, are affected in the scenarios simulated previously with relatively high water depths depending on the simulated source. In what concerns the maximum flow depth over Huelva we conclude that the area of las Marismas is widely flooded in all its extension with 2 to $5 \mathrm{~m}$ height in general. This was expected and matches historical data for the 1755 event. According to the different sources considered here, simulated maximum flow depths vary from 2.3 to $6.3 \mathrm{~m}$ and simulated maximum run-up in a range of 1.4 to $5.2 \mathrm{~m}$. The highest value is reached for the case of the Horseshoe Fault.

From the study made for the sensitivity of two basic impact parameters (maximum flow depth and maximum runup) with respect to dip, slip and strike of the source, we conclude that the maximum flow depths increase with increasing values of slip; the variation of slip seems to have a great influence in the run-up obtained in Huelva, but looking at Tables 1 and 2 we see that our observations do not agree with what is expected from the Plafker's rule of thumb (Okal and Synolakis, 2004), which says that the ratio between the maximum run-up and the average slip on the fault plane cannot be much greater than 1 on a nearby beach with a smooth topography. This is a consequence of the complex topographic characteristics of the study area, where the maximum altitude of the Juan Carlos I dock (13 km long dock of flow-over type displayed in Fig. 1a), which is a very large dike, is only $3.5 \mathrm{~m}$, thus bounding the maximum run-up reachable in the dike area (see the local maxima of the run-up height curves in Fig. 5); only sources able to generate inundation flows that reach further in-land, as is the case of the CWF and the HSF, can generate higher run-up values. For most of the cases we obtained a ratio close to 1 .

With the increase of the source strike the maximum flow depth and the run-up increase also. The influence of the source strike in run-up and water depth is not critical. This is a consequence of the fact that Huelva is already far from the presumed active sources and only very large changes in strike can generate significantly different inundation patterns.

The results on the variation of the inundation parameters according to the tidal levels account for a difference in run-up of the order of magnitude of only $1 \mathrm{~m}$.

In all studied situations the advance of tsunami waves is done through the rivers Odiel and Tinto to land. In this sense, finer and better topographic data could be useful to assess the inland inundation, whose extent is probably affected by the limits of our study area.

The importance of the tidal level on the eventual tsunami effects is more important in what concerns maximum flow depth than in what concerns maximum run-up. When com- pared to a simulation corresponding to "mean sea level" conditions, the effect of the tide can account for an extra $1.5 \mathrm{~m}$ of water depth and less than $1 \mathrm{~m}$ in maximum run-up.

Finally, we must consider the comparison between this inundation study and the historical records related with the 1 November 1755 tsunami. Among the candidate sources described in Table 1 only CWF is able to produce massive inundation of "las Marismas" as described, but other candidates (e.g. PBF, HSF, and Ext. MPF) also generate partial inundation of the area. The large values of MID along Odiel river, described by historical records, and needed to support the sedimentary evidence, are also well reproduced by most sources, with the single exception of Gorringe Bank fault. Inundation of Huelva downtown is not well reproduced by any of the candidate sources. This can be a consequence of the present day morphology, or an indication that the historical record is compatible with events even larger than those considered here and so larger (or combined) sources must be considered for the worst yet credible scenario.

Acknowledgements. This study was funded by TRANSFER Project, contract STREP 37058 UE. Information regarding tsunami sources was made available by NEAREST Project, contract STREP 037110. The authors wish to thank the support of Stefano Tinti and Nevio Zittelini, principal investigators of the above projects and to our colleagues Pedro Terrinha, Luis Matias and Marc-Andre Gutscher, with which we had many fruitful discussions.

Edited by: S. Tinti

Reviewed by: A. Babeyko and another anonymous referee

\section{References}

Anonymous: Nuevo y Curioso Romance Del Estrago causado el dia de Todos os Santos en la Villa d Huelva, declara-se como reventó el Mar, y el Rio, pereciendo mas de mil personnas arruinados los Templos, y las Casas, y asstiendo los pocos vecinos, que Ham quedado; dad noticia, como cayendo en el Convento de la Victoria parte de su Templo, y Altar Mayor, entr sus ruinas se encontró el Sagrario todo rompido, menoe el el Sagrado que lo cubri milagrosamente en medio ladrillo, con outras, particularidades, Manuscript, Arquivo Nacional da Torre do Tombo, 1755 (in Spanish).

Baptista, M. A. and Miranda, J. M.: Revision of the Portuguese catalog of tsunamis, Nat. Hazards Earth Syst. Sci., 9, 25-42, 2009, http://www.nat-hazards-earth-syst-sci.net/9/25/2009/.

Baptista, M. A., Heitor, S., Miranda, J. M., Miranda, P., and Mendes Victor, L.: The 1755 Lisbon Tsunami: Evaluation of the Tsunami parameters, J. Geodyn., 25(2), 143-157, 1998a.

Baptista, M. A., Miranda, P., Miranda, J. M., and Mendes Victor, L.: Constrains on the source of the 1755 Lisbon tsunami inferred from numerical modelling of historical data, J. Geodyn., 25, 159-174, 1998b.

Bondevik, S., Løvholt, F., Harbitz, C., Mangerud, J., Dawson, A., and Svendsen, J. I.: The Storegga Slide Tsunami - Comparing Field Observations with numerical simulations, Mar. Petrol. Geol., 22, 195-208, 2005. 
Bondevik, S., Mangerud, J., Dawson, S., Dawson, A. G., and Lohne, O.: Record-breaking height for 8000 years-old tsunami in the North Atlantic, EOS T. Am. Geophys. Un., 84, 289-300, 2003.

Dawson, A. G., Hindson, R., Andrade, C., Freitas, C., Parish, R., and Bateman, M.: Tsunami sedimentation associated with the Lisbon earthquake of 1 November AD 1755: Boca do Rio, Algarve, Portugal, The Holocene, 5(2), 209-215, 1995.

Geist, E. L. and Dmowska, R.: Local tsunamis and distributes slip at the source, Pure Appl. Geophys., 154:485-512, 1999.

Gutscher, M. A., Roger, J., Baptista, M. A., and Miranda, J. M.: The source of the 1693 Catania earthquake and tsunami (Southern Italy): New evidence from tsunami modeling of a locked subduction fault plane, Geophys. Res. Lett., 33, L08309, doi:10.1029/2005GL025442, 2006.

Hindson, R. A., Andrade, C., and Dawson, G.: Sedimentary processes associated with the tsunami generated by the 1755 Lisbon earthquake on the Algarve Coast, Portugal, Phys. Chem. Earth, 21(12), 57-63, 1996.

Horsburgh, K. J., Wilson, C., Baptie, B. J., Cooper, A., Cresswell, D., Musson, R. M. W., Ottemöller, L., Richardson, S., and Sargeant, S. L.: Impact of a Lisbon-type tsunami on the U.K. coastline and the implications for tsunami propagation over broad continental shelves, J. Geophys. Res., 113, C04007, doi:10-1029/2007JC004425, 2008.

Instituto Geográfico Nacional : Terremotos Y Tsunamis en España, $\mathrm{CD}, 2005$.

Kerridge, D.: The threat posed by tsunamis to the UK, Report, Study commissioned by Defra Flood Management and produced by British Geological Survey, 2005.

Liu, P. L.-F., Cho, Y.-S., Briggs, M. J., Synolakis, C. E., and Kanoglu, U.: Run-up of Solitary Waves on a Circular Island, J. Fluid Mech., 302, 259-285, 1995.

Liu, P. L.-F., Cho, Y.-S., Yoon, S. B., and Seo, S. N.: Numerical simulations of the 1960 Chilean tsunami propagation and inundation at Hilo, Hawaii, Recent Development in Tsunami Research, edited by: El-Sabh, M. I., Kluwer Academic Publishers, 1994b.

Liu, P. L.-F., Woo, S.-B., and Cho, Y.-S.: Computer programs for tsunami propagation and inundation, Cornell University, 1998.

Liu, P. L.-F. and Cho, Y.-S.: An integral equation model for wave propagation with bottom friction, J. Waterway. Div. ASCE, 120, 594-608, 1994a.

Luis, J. F.: Mirone: A multi-purpose tool for exploring grid data, Comput. Geosci., 33, 31-41, 2007.

Luque, L., Lario, J., Zazo, C., Goy, J. L., Dabrio, C. J., and Silva, P. G.: Tsunami deposits as paleoseismic inidcators: examples from the Spanish coast, Acta Geologica Hispanica, 36(3-4), 197-22, 2001.

Manighetti, I., Campillo, M., Bouley, S., and Cotton, F.: Earthquake scaling, fault segmentation, and structural maturity, Earth Planet. Sc. Lett., 253(3-4), 429-438, 2007.

Mansinha, L. and Smylie, D. E.: The Displacement Field of Inclined Faults, B. Seismol. Soc. Am., 61, 1433-1440, 1971.

Mascarenhas, J.: Gazeta de Lisboa, 46, 361-367, 13 de Novembro de 1755 (in Portuguese).

Miranda, J. M., Baptista, M. A., Terrinha, P., and Matias, L.: Tsunamigenic source areas for Portugal mainland, Iberia, Oral Communication, session Tsunami Early Warning Systems and Tsunami Risk Mitigation in the European-Mediterranean Re- gion, 31 General Assembly of the European Seismological Commission, Crete, Greece, September 2008.

Morales, J. A., Borrego, J., San Miguel, E. G., López-González, N., and Carro, B.: Sedimentary record of recent tsunamis in the Huelva Estuary (southwestern Spain), Quaternary Sci. Rev., 27, 734-746, 2008.

Okal, E. and Synolakis, C.: Source discriminants for near-field tsunamis. Geophys. J. Int., 158, 899-912, 2004.

Pirazzoli, P. A.: Sea-level changes: the last 20000 years, Wiley, London, 1996.

Richardson, S.: Tsunamis - Assessing the Hazard for the UK and Irish Coasts. HR Wallingford Report EX 5364. Study commissioned by Defra Flood Management Division, the Health and Safety Executive and the Geological Survey of Ireland, 2006.

Romero, M. L. C.: El riesgo de Tsunamis en España. Analisis y valoración geográfica, Instituto Geográfico Nacional, Madrid, 204 pp., ISBN:84-7819-041-4, 1992.

Ruiz, F., Rodríguez-Ramírez, A., Cáceres, L. M., Vidal, J. R., Carretero, M. I., Abad, M., Olías, M., and Pozo, M.: Evidence of high-energy events in the geological record: Mid-holocene evolution of the southwestern Doñana National Park (SW Spain), Palaeogeogr. Palaeocl., 229, 212-229, 2005.

Solares, J. M. M. and López Arroyo, A.: The great historical 1755 earthquake. Effects and damage in Spain, J. Seismol., 8, 275294, 2004.

Solares, J. M. M.: Los efectos e España del terremoto de Lisboa (1 de Noviembre de 1755). Instituto Geográfico Nacional, Madrid, 756 pp, 2001.

Terrinha, P., Matias, L., Vicente, J., Duarte, J., Luís, J., Pinheiro, L., Lourenço, N., Diez, S., Rosas, F., Magalhães, V., Valadares, V., Zitellini, N., Mendes Víctor, L., and MATESPRO Team: Morphotectonics and Strain Partitioning at the Iberia-Africa plate boundary from multibeam and seismic reflection data, Mar. Geol., 267, 156-174, doi:10:1016/j.margeo.2009.09.012, 2009.

Tinti, S. and Maramai, A.: Catalogue of tsunamis generated by Italy and in Côte d'Azur, France: a step towards a unified catalogue of tsunamis in Europe, The Third International Workshop on LongWave Run-up Models, 17-18 June 2004, Wrigley Marine Science Center, Catalina Island, California, Ann. Geofis., 39(N6), 1253-1299, 1996.

Wang, X. and Liu, P. L.-F.: COMCOT User Manual - Version 1.6., School of Civil and Environmental Engineering, Cornell University, Ithaca, NY 14853, USA, available at: http://ceeserver.cee. cornell.edu/pll-group/doc/comcot_user_manual_v1_6.pdf, 2006a.

Wang, X. and Liu, P. L.-F.: A numerical investigation of Boumerdes-Zemmouri (Algeria) Earthquake and Tsunami, Computer Modeling in Engineering and Sciences, 10(2), 171-184, 2005.

Wang, X. and Liu, P. L.-F.: Numerical simulations of the 2004 Indian Ocean tsunamis - Coastal effects, J. Earthq. Tsunami, 1(3), 273-297, 2007.

Wang, X. and Liu, P. L.-F.: An analysis of 2004 Sumatra earthquake fault plane mechanism and Indian Ocean tsunami, J. Hydraul. Res., 44(2), 147-159, 2006b.

Zitellini, N., Gràcia, E., Matias, L., Terrinha, P., Abreu, M. A., DeAlteriis, G., Henriet, J. P., Dañobeitia, J., Masson, D. G., Mulder, T., Ramella, R., Somoza, L., and Diez, S.: The quest for the Africa-Eurasia plate boundary west of the Strait of Gibraltar, Earth Planet. Sc. Lett., 280(1-4), 13-50, 15 April 2009. 